\title{
ANALISIS ANGGARAN BIAYA PEMASARAN SEBAGAI ALAT PENILAIAN KINERJA PADA PT. PENERBIT ERLANGGA CABANG BENGKULU
}

\author{
Wirosman Wehalo \\ Nani Halima Zahara \\ Program Studi Akuntansi \\ Fakultas Ekonomi Universitas Dehasen Bengkulu
}

\begin{abstract}
ABSTRAK
Wirosman Wehalo, Nani Halima Zahara; Tujuan penelitian ini adalah untuk menganalisis apakah anggaran biya pemasaran dapat digunakan sebagai alat penilaian kinerja perusahaan, perusahaan ini fokus pada perusahaan dagang dimana setiap Hak Ciptanya telah dilindungi oleh Undang-Undang selama periode tahun 2007 sampai pada saat ini. Jenis penelitian yang digunakan dalam penelitian ini adalah penelitian deskriptif komparatif yaitu membandingkan persamaan dan perbedaan dua atau lebih faktafakta dan sifat-sifat objek yang di teliti berdas arkan kerangka pemikiran tertentu. Objek penelitian dalam penelitian ini adalah PT. Penerbit Erlangga Cabang Bengkulu. Dari data yang sudah diperoleh dari tahun 2007 sampai dengan tahun 2012 menunjukkan anggaran biaya sudah berfungsi sebagai alat penilaian kinerja, karena dalam menilai kinerja pada tiap cabang perusahaan membandingkan antara anggaran dan realisasi yang kemudian ditelusuri penyebab tersebut.
\end{abstract}

\section{ABSTRACT}

Wirosman Wehalo, Nani Halima Zahara; The purpose of this study was to analyze whether the marketing budget can be used as a performance assessment tool company, the company is focused on trading company where any Copyrighted has been protected by the Act during the period of 2007 until today. Types of research used in this study was a comparative descriptive study was to compare the similarities and differences in two or more of the facts and the object properties in the framework based on certain carefully. Research object in this study is PT. The publisher Erlangga Bengkulu branch. from 2007 to 2012 showed the budget is already functioning as a performance assessment tool, because in assessing the performance of each branch of the company to compare between the budget and the realization that the cause was traced.

Key words: Marketing costs, revenues, performance

\section{PENDAHULUAN}

Kinerja merupakan hasil akhir dari aktivitas baik individu maupun perusahaan. Perusahaan sering menjadikan kenerja sebagai sebuah nilai yang akan menjadi tolak ukur berhasil atau tidaknya suatu perusahaan dalam merealisasikan perencanaan perusahaan tesebut. Mengukur kinerja dalam perusahaan tidak terlepas dari analisis keuangan. Kondisi keuangan mencerminkan arus kas dalam mencapai profabilitas yang diinginkan oleh pemilik perusahaan (Mulyadi, 2001:22). Analisis keuangan tidak terlepas dari anggaran. Anggaran merupakan alat manajemen dalam mencapai tujuan (Nafarin, 2000:7). Anggaran menyediakan standar untuk melakukan evaluasi kinerja dalam perusahaan. Evaluasi kinerja dalam anggaran diukur dengan membandingkan hasil realisasi dengan anggaran yang sudah dianggarkan perusahaan. Anggaran memegang peranan penting dalam dunia usaha. Hal ini dikarenakan anggaran menyajikan informasi mengenai kegiatan operasional perusahaan dalam satu periode tertentu agar tujuan dari perusahaan dapat tercapai semaksimal mungkin. Untuk mencapai tujuan tersebut 
perusahaan perlu menyusun perencanaan (anggaran) yang menyeluruh tentang kegiatan perusahaan untuk waktu yang akan datang dan dibuat berdasarkan data waktu sebelumnya yang disesuaikan dengan kondisi yang akan datang.

Kegiatan perusahaan yang tidak terencana dengan baik maka pelaksanaan tidak efektif dan efesien, dengan demikian diperlukan langkahlangkah dari pihak manajemen perusahaan untuk menyusun strategi serta mengukur pelaksanaan strategis tersebut, apakah mencapai sasaran atau tidak. Penyusunan strategi tersebut dijabarkan dalam nilai uang yang disebut dengan anggaran. Dengan adanya anggaran maka perusahaan dapat mengetahui terjadinya penyimpangan yang akan timbul dalam rangka menjalankan kegiatan perusahaan yakni dengan cara membandingkan anggaran dengan data aktual atau realisasinya. Salah satu fungsi anggaran yaitu sebagai alat pengawasan, dimana anggaran biaya yang dikeluarkan oleh perusahaan tetap diawasi dan dikendalikan.

Persaingan yang sedemikian tajam, menyebabkab perusahaan sekarang tidak dapat hanya menitikberatkan pada tujuan penjualan dengan biaya produksi seminimal mingkin. Ini bukan berarti penjualan harus diabaikan, bahkan menjadi sangat penting karena pendapatan yang diperoleh berasal dari penjualan. Dengan demikian perusahaan dituntut untuk berorientasi kepada pembeli/ konsumen/ pasar, yang berarti bahkan kerangka pikir pemasaran dimulai dari penempatan knsumen sebagai titik tolak usaha perusahaan dan penekanan perlunya keahlian pemasaran dan pembinaan distribusi pemasaran. Dengan kata lain perusahaan hendaknya menerapkan orientasi pasar tersebut dengan mangarahkan karyawan, bahan baku, dan uang yang di kuasainya secara efesien untuk memenuhi kebutuhan konsumen sekaligus memperoleh laba yang optimal dengan biaya yang minimal.

Pemasaran yang berhasil akan mendorong peningkatan produksi, sebaliknya dengan tingkat produksi yang tinggi belum tentu dapat menjamin keberhasilan dibidang pemasaran. Oleh karena itu, jika volume produksi dapat ditingkatkan tetapi tidak dapat memasarkannya, maka usaha tersebut sia-sia. Biaya pemasaran ini termasuk dalam discretionary Cost, yaitu output yang dihasilkan tidak dikaitkan langsung dengan input.

Selain itu pendapatan dipengaruhi bukan hanya oleh biaya pemasaran, tetapi juga banyak faktor yang mempengaruhi seperti faktor manejerial dan lain-lain. Perhatian perusahaan dalam pengendalian biaya-biaya pemasaran terhadap produk, daerah pemasaran atau pelanggan dan jumlah pesanan pembelian sangatlah penting, oleh karena itu perlu dilakukan analisis atas probabilitas pemasaran yang dapat mengarahkan kegiatan pemasaran agar tidak terjadi pengurangan pendapatan.

PT. Penerbit Erlanggga merupakan salah satu perusahaan yang bergerak dalam bidang jasa dan dagang, yang hadir pada tahun 1952. Dan melayani semua ilmu pengetahuan dalam pengembangan kompetensi sumber daya manusia diseluruh jenjang pendidikan. Mulai dari Taman Kanak-kanak (TK) sampai dengan perguruan tinggi (PT). Yang memiliki 16 kantor cabang di Indonesia dan salah satunya adalah di Provinsi Bengkulu. Dalam hal pengeluaran biaya-biaya operasional terlebih dahulu menyusun anggaran yang nantinya dijadikan sebagai standar pelaksanaan biaya operasional termasuk biaya pemasaran atau marketing.

Pemasukan atau pendapatan yang diperolah oleh purusahaan khususnya dari departemen pemasaran dari periode tahun 2007 sampai dengan tahun 2012, mengalami penyimpangan yang tidak menguntungkan bagi perusahaan. Mengingat pentingnya anggaran biaya pemasaran oleh perusahaan maka peneliti tertarik untuk menganalisis dan meniliti dalam bentuk skripsi dengan judul "Analisis Anggaran Biaya Pemasaran Sebagai Alat Penilaian Kinerja Pada PT. Penerbit Erlangga Cabang Bengkulu".

\section{Landasan Teori Anggaran}

Menurut Nafarin (2000: 9), “Anggaran (budget) merupakan rencana tertulis mengenai kegiatan suatu organisasi yang dinyatakan secara kuantitatif dan umumnya dinyatakan dalam satuan uang untuk jangka waktu tertentu." Sedangkan menurut rudianto (2009: 3), anggran adalah rencana kerja organisasi dimasa mendatang yang mewujudkan dalam bentuk 
kuantitatif, formal, dan sistematis. Rencana kerja perusahaan tersebut ditulis dalam bentuk sederatan angka yang merupakan target pencapaian perusahaan.

Dari pengertian di atas maka dapat disimpulkan bahwa anggaran adalah merupakan suatu budget atau rencana tertulis dalam bentuk angka yang dinyatakan dalam unit moneter atau secara kuantitatif, dalam jangka waktu tertentu dimasa yang akan datang. Penyusunan anggaran adalah proses penentuan peran setiap manager dalam melaksanakan program atau bagian program. Misalnya dari tahap persiapan yang diperlukan sebelum dimulainya suatu rencana pengumpulan berbagai data dan informasi yang diperlukan, pembagian tugas perencanaan, penyusunan rencana tersendiri, implementasi dari rencana tersebut sampai pada akhirnya tahap pengawasan dan evaluasi dari hasil pelaksanaan rencana itu dipertanggungjawabkan kepada manajer yang telah ditetapkan.

Manajer adalah penanggung jawab dari pusat pertanggung jawaban. Pusat pertanggung jawaban itu sendiri merupakan suatu bagian, segmen atau sub unit dari satu organisasi dimana manajer bertanggung jawab untuk aktivitas yang ditentukan. Anggaran yang telah disahkan merupakan kesanggupan atau kontinyu manajer pusat pertanggung jawaban untuk melaksanakan rencana seperti tercantum dalam anggaran dan digunakan sebagai alat pengendali kegiatan.

\section{Biaya}

Di dalam menganalisis break Event point, hal yang paling di singgung adalah masalah biaya. Karena biaya merupakan salah satu unsur pokok yang paling penting dalam analisis. Menurut Hansen \& Mowen (2000:47), Biaya adalah kas atau Ekuivalen kas yang dikorbankan untuk barang atau jasa yang diharapkan membawa keuntungan pada masa kini dan masa yang akan datang dalam sebuah organisasi. Jadi biaya di keluarkan untuk menghasilkan manfaat di masa depan. Dalam perusahaan, manfaat dimasa depan biasanya berarti pendapatan. Jadi, biaya digunakan untuk memproduksi pendapatan.

Penggolongan biaya menurut perilakunya dalam hubungannya dengan volume kegiatan. Kebehasilan dalam perencanaan dan pengendalian biaya tergantung pada pemahaman yang menyeluruh mengenai hubungan antara terjadinya biaya dan kegiatan bisnis. Telah dan analisis yang cermat, yang mempengaruhi kegiatan bisnis terhadap biaya umumnya akan menghasilkan pengggolongan setiap jenis pengeluaran kedalam biaya tetap,variable, atau semivariabel.

\section{a. Biaya Tetap (Fixed Cost)}

Menurut Hansen \& Mowen (2000: 55) biaya tetap adalah biaya yang tetap sama dalam jumlah seiring dengan kenaikan atau penurunan keluaran kegiatan. Sedangkan menurut Zulkifli (2003 : 34) adalah biaya yang jumlahnya sampai tingkat kegiatan tertentu relatif tetap dan tidak terpengaruh oleh perubahan volume kegiatan Jadi, dari pengertian diatas penulis simpulkan bahwa biaya tetap adalah biaya yang sifatnya tetap walaupun kegiatan produksinya berubah-ubah. Meskipun beberap jenis biaya tampak tetap, namun dalam jangkan panjang semua biaya adalah variable. Jika semua kegiatan bisnis menurun sampai Nol dan tidak ada prospek bagi kegiatan tersebut untuk meningkat, perusahaan akan melakukan likuidasi, dengan demikian perusahaan akan menghindari semua biaya. Jika kegiatan diharapkan meningkat sampai melebihi kapasitas yang ada saat ini, biaya tetap harus tetap ditingkatkan untuk mengimbangi kelebihan volume tersebut. Contoh biaya tetap : beban penyusutan, beban sewa, asuransi kekayaan, pajak bimu dan bangunan dan lain-lain.

Jika menajemen mengharapkan permintaan atas produk perusahaan akan meningkat samapi melebihi kapasitas dari fasilitas saat ini, maka manajemen harus mengupayakan tambahan pabrik dan peralatan, dan mungkin tenaga kerja. Akibatnya, perusahaan akan mengalami peningkatan biaya variabel. 
Untuk itu, jenis pengeluaran tersebut sebagai biaya tetap hanya dalam rentang kegiatan yang terbatas. Rentang kegiatan yang terbatas ini disebut dengan rentang yang releva. Total biaya tetap akan berubah di luar rentang kegiatan yang relevan. Perubahan biaya tetap pada tingkat kegiatan yang berbeda dan rentang yang relevan dapat dilihat dalam gambar berikut ini :

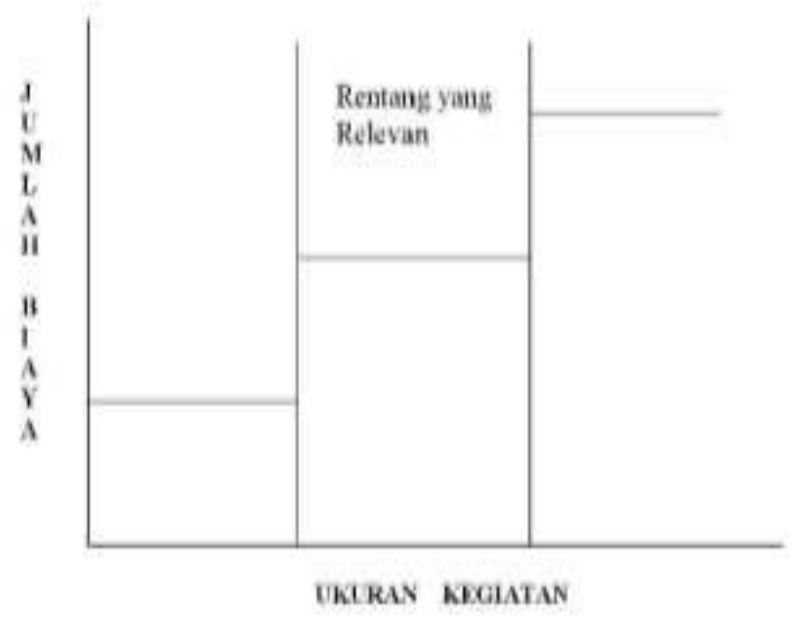

Sumber : Hansen \& Mowen yang dialiblbahisakan oleh Aneclla

A. Itemawan (2006) s8)

Gambar 1 : Biaya Tetap b. Biaya Variabe (Variable Cost)

Menurut Hansen \& Mowen yang dialihbahasakan oleh Hermawan (2000: 70) di sebutkan bahwa biaya variabel ialah biaya yang meningkat dalam total seiring dengan peningkatan keluaran kegiatan dan menurun dalam total seiring dengan penurunan kelauaran kegiatan.

Sedangkan menurut Supriyono (2000 : 185), Variable cost (biaya variabel) adalah biaya yang jumlah totalnya berubah sebanding dengan perubahan volume kegiatan. Biaya variabel per unit konstan (tetap) dengan adanya perubahan volume kegiatan. Contoh: biaya bahan baku, biaya iklan dan komisi untuk seorang selesman sesuai dengan levelnya

Jadi, dari pengertian diatas penulis simpulkan bahwa biaya variabel adalah biaya yang secara total berubah proporsional seiring dengan perubahan kegiatan produksi. Biaya variabel meliputi biaya langsung, pekerja langsung, bahan penolong tertentu, biaya pengerjaan ulang. Biasanya biaya variabel secara langsung di identifikasikan dengan kegiatan yang mengakibatkan adanya biaya tersebut.

Dalam praktiknya, hubungan antara kegiatan produksi dengan biaya variabel yang ditimbulkannya biasanya dianggap seakan-akan bersifat linier. Total biaya variabel dianggap meningkat dalam jumlah yang konstan untuk peningkatan setiap unit kegiatan. Namun, hubungan yang sebenarnya sangat jarang bersifat linier secara sempurna pada seluruh rentang relevan yang mungkin. Misalnya pada saat volume kegiatan sampai ketingkat tertentu. Barangkali manajemen akan menambah mesin prosuksi yang beru. Akibatnya biaya kegiatan per unit akan berbeda-beda pada berbagai tingkat kegiatan. Meskipun demikian, dalam rentang relevan tertentu, hubungan antara kegiatan dan biaya variabelnya kurang lebih bersifat linier.

Hubugan ini ditunjukkan dalam gambar 2 dibawah ini. Garis B menggambarkan biaya variabel actual pada semua tingkat kegiatan, dan garis A menunjukkan biaya variabel yang dihitung pada semua tingkat yang ditentukan berdasarkan opbservasi pada rentang relevan. Dapat digambarkan pada gambar berikut : 
Gambar 2 : biaya variabel

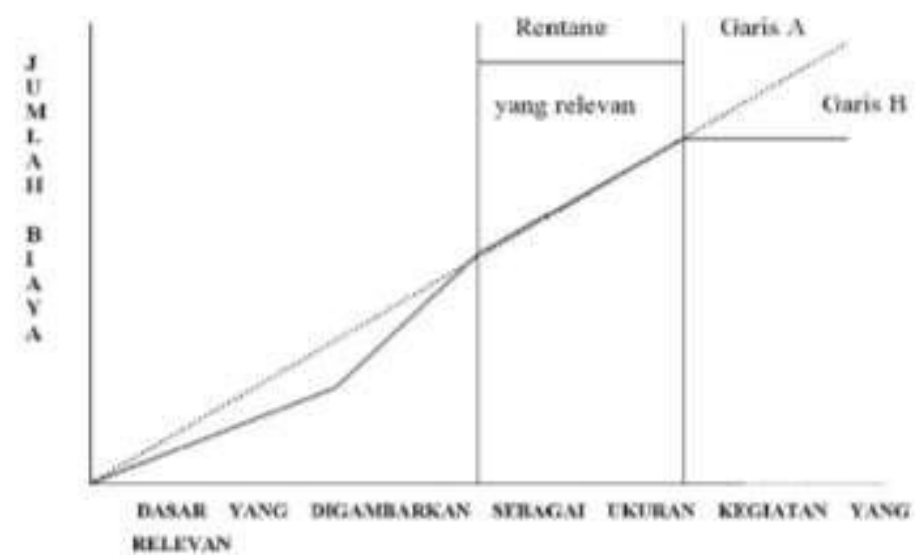

Sumber : Hansen \& Mowen yang dialihbahasakan oleh Ancella Hermawan 2000: 70)

\section{c. Biaya Semi Variabel}

Menurut Carter dan Usri yang di alihbahasakan oleh Krista (2001: 45) yang di sebutkan bahwa "Biaya Semivariabel di deveinisikan sebagai sebagai biaya yang memperlihatkan baik yang karakteristik dari biaya tetap maupun daribiaya variabel". Sedangkan menurut Hansen \& Mowen yang dialihbahasakan oleh Hermawan (2000: 87) di sebutkan bahwa "biaya semivariabel (campuran) ialah biaya yang memiliki komponen biaya tetap dan biaya variabel. Dari pengertian di atas penulis simpulkan bahwa biaya semivariabel merupakan biaya yang mengandung sifat biaya tetap dan biaya variabel. Misalnya pemeliharaan, biaya pensiun, pajak atau upah dan perjalanan serta hiburan.

Biaya variabel dapat digambarkan dibawah ini. Garis pada gambar tersebut menunjukkan biaya actual pada semua tingkat produksi. Dalam gambar ini,garis biaya actual (Garis C) tidak linear. Ini bias terjadi karena penggunaan teknik atau peralatan produksi yang berbeda atau tingkat penggunaan kapasitas yang berbeda pada tingkat produksi yang berbeda. Garis putus-putus merupakan garis yang menunjukkan jumlah unsure tetap dan variabel dari semi variabel (garis A dan garis B) pada semua tingkat kegiatan yang ditentukan berdasarkan observasi dalam tingkat relevan.

Apabila garis B dan garis $\mathrm{C}$ yang tidak terputus berhimpit, maka asumsi linear sangat mendekati hubungan yang sebenarnya. Daerah yang berhimpitan ini merupakan rentang yang relevan. Penggunaan biaya tetap dan tarif biaya variabel yang telah dihitung untuk memperkirakan biaya pada setiap tingkat kegiatan di luar rentang yang relevan akan menghasilkan estimasi yang tidak dapat diandalkan.

Gambar 3 : biaya semi variabel

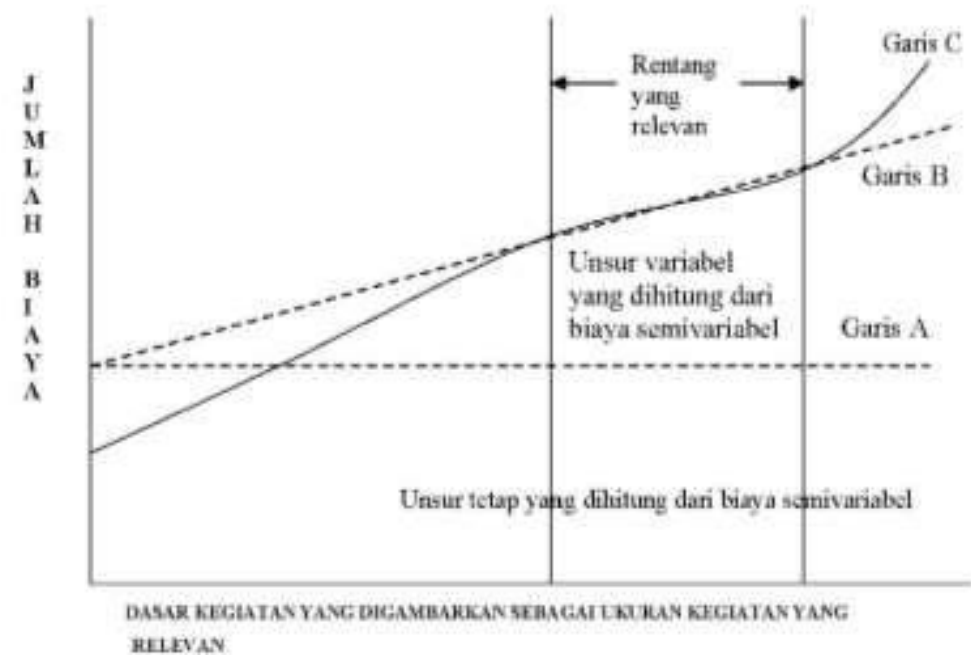

Sumber : Hansen \& Women yang dialihbahasakan oleh Ancella A. Hermawan (2000: 87) 


\section{Pemasaran}

Pemasaran berasal dari kata market (pasar). Pasar adalah sekumpulan seluruh pembeli yang aktual dan potensial dari suatu produk. Menurut Mursid (2003 : 26 ), pengertian pemasaran adalah "Suatu proses perpindahan barang atau jasa dari tangan produsen ke tangan konsumen".

Menurut Kotller (2010 : 3), menyatakan bahwa pengertian pemasaran adalah "Marketing is a social and managerial process by which individual and group obtain what they need and want through creating, offering and freely exchanging product and services of value with other"

Berdasarkan pengertian di atas maka dapat disimpulkan bahwa pemasaran adalah suatu proses manajerial dimana individu atau kelompok memperoleh apa yang mereka inginkan melalui kegiatan penawaran barang. Konsumen memiliki cara yang berbeda-beda untuk memenuhi kebutuhan. Apabila mereka mempunyai kebutuhan maka mereka akan memilih produk atau jasa yang memberikan keuntungan besar. Perkembangan dunia usaha dewasa ini menunjukan bahwa kunci keberhasilan perusahaan adalah mengetahui dan memuaskan kebutuhan konsumen. Hal ini dapat dilakukan melalui kegiatan pemasaran.

a. Promosi

Seiring dengan diluncurkannya suatu produk di pasar maka diperlukan suatu usaha perusahaan untuk menginformasikan segala hal yang berhubungan dengan produk tersebut kepada konsumen, antara lain nama produk, keunggulan dibandingkan dengan produk lain yang sejenis, dimana produk tersebut diperoleh, serta produsen produk tersebut. Informasi tersebut bertujuan agar produk perusahaan dikenal oleh konsumen. Segala informasi mengenai produk tersebut bersifat membujuk dan dikemas dalam bentuk yang komunikatif sesuai dengan sasaran konsumen inilah yang disebut sebagai promosi.

Promosi adalah komunikasi antar produsen dengan konsumen mengenai suatu produk dengan tujuan untuk mempengaruhi perilaku konsumen agar mengkonsumsi produk tersebut sehingga dapat meningkatkan penjualan.

Pengertian promosi menurut Saladin (2003 : 171), Promosi adalah salah satu unsur dalam bauran pemasaran perusahaan yang didayagunakan untuk memberitahukan, membujuk dan mengingatkan tentang produk perusahaan"

Menurut Alma (2000 : 135), Promosi adalah sejenis komunikasi yang memberi penjelasan yang meyakinkan calon konsumen tentang barang dan jasa“"

Berdasarkan pengertian di atas maka dapat disimpulkan bahwa promosi adalah suatu jenis komunikasi dalam unsur bauran pemasaran perusahaan yang bertujuan untuk memberitahukan, membujuk dan memberi penjelasan untuk meyakinkan konsumen tentang barang dan jasa yang dihasilkan perusahaan.

b. Alat-alat Promosi Menurut Swastha (2000 : 350), menyatakan alat-alat promosi terdiri dari:

1) Periklanan Merupakan bentuk presentasi dan promosi non pribadi tentang ide, barang dan jasa yang dibayar oleh sponsor tertentu.

2) Personal Selling

3) Merupakan presentasi lisan dalam suatu percakapan dengan suatu calon pembeli atau lebih yang ditujukan untuk menciptakan penjualan.

4) Publisitas Merupakan pendorongan permintaan secara non pribadi untuk suatu produk, jasa atau ide dengan menggunakan berita komersial di dalam media massa dan sponsor tidak dibebani sejumlah bayaran secara langsung.

5) Promosi Penjualan Merupakan kegiatan pemasaran selain personal selling, periklanan dan publisitas yang mendorong pembelian konsumen dan efektifitas pengecer. Kegiatan-kegiatan tersebut antara lain peragaan, pertunjukan dan pameran, demonstrasi dan lain-lain. 
c. Tujuan Promosi

Tujuan utama promosi adalah memberi informasi, menarik perhatian dan selanjutnya memberi pengaruh meningkatnya penjualan. Suatu kegiatan promosi jika dilaksanakan dengan baik dapat mempengarui konsumen mengenai dimana dan bagaimana konsumen membelanjakan pendapatannya. Promosi membawa keuntungan baik bagi produsen maupun konsumen. Keuntungannya bagi konsumen adalah konsumen dapat mengatur pengeluarannya menjadi lebih baik. Kerugiannya bagi konsumen adalah mereka dibujuk untuk membeli barang yang kadang-kadang barang tersebut belum dibutuhkannya.

Keuntungannya bagi produsen adalah promosi dapat menghindarkan persaingan berdasarkan harga karena konsumen membeli barang karena tertarik akan mereknya. Promosi menimbulkan goodwill terhadap merek. Promosi bukan hanya meningkatkan penjualan tapi juga dapat menstabilkan produksi. Menurut Swastha (2000 : 253), menyatakan tujuan promosi ada 4 yaitu : 1) Modifikasi Tingkah Laku

Orang-orang melakukan komunikasi karena beberapa alasan, yaitu mencari kesenangan, mencari bantuan, memberikan pertolongan atau istruksi, memberikan informasi, mengemukakan ide dan pendapat. Sedangkan promosi berusaha untuk mengubah

tingkah laku dan pendapat. 2) Memberitahu Kegiatan promosi ditujukan untuk memberitahu pasar yang dituju tentang penawaran perusahaan. Sebagian orang tidak akan membeli barang atau jasa sebelum mereka mengetahui produk tersebut dan apa faedahnya. Promosi yang bersifat informative ini penting bagi konsumen karena dapat membantu dalam pengambilan keputusan untuk membeli. 3) Membujuk Promosi ini diarahkan untuk mendorong pembelian. Promosi ini umumnya kurang disukai oleh sebagian masyarakat. 4) Mengingatkan Promosi yang bersifat mengingatkan dilakukan untuk mempertahankan merek produk di hati masyarakat dan perlu dilakukan selama tahap kedewasaan di dalam siklus kehidupan produk. Ini berarti perusahaan berusaha untuk mempertahankan pembeli yang ada.

d. Promotion Mix Dalam promotion mix ada 2 cara yang paling ampuh yang dikemukakan oleh Alma (2000 : 173) antara lain : 1) Advertising Advertising sudah diyakini keampuhannya untuk memikat hati konsumen. Advertising bisa mencapai jarak jauh dan memasuki masyarakat luas, tapi advertising tidak punya kemampuan dalam melakukan transaksi advertising bersifat satu arah atau sepihak saja. 2) Personal Selling

Pelayanan pramuniaga, penjual keliling sangat ampuh melayani konsumen. Mereka mampu berdialog dengan konsumen, bisa mengatasi keberatan yang diajukan, bisa memberi informasi dan bisa pula mencatat apa kemauan atau bagaimana selera konsumen yang dihadapinya.

e. Anggaran Promosi

Anggaran promosi yang disusun tergantung besar kecilnya perusahaan. Jenis produk yang dihasilkan dan ragam kegiatan yang ada pada masing-masing perusahaan. Dalam perencanaan anggaran promosi terkadang dipergunakan taksiran-taksiran yang tidak selalu tepat dan sangat sulit diprediksi, yang mempertimbangkan berbagai data, informasi dan faktor baik yang controllable maupun yang uncontrollable.

Anggaran promosi yang disusun harus realistis, berdasarkan analisis yang diteliti mengenai setiap tindakan yang akan dilakukan dan mungkin untuk dicapai, luwes dan tidak kaku sehingga memungkinkan perubahan sesuai situasi dan kondisi, selalu disesuaikan dengan keadaan yang berubah-ubah secara periodik dan harus kontinyu, artinya kelangsungan perencanaan anggaran terjaga dan bukan merupakan kegiatan insidental.

Karena anggaran promosi bersifat formal, disusun secara resmi dan tertulis sistematis, berurutan dan berdasarkan suatu fakta atau logika dan memutuskan apa yang akan dilakukan dimasa yang akan datang. Maka isinya menyangkut komitmen manajemen diamana para manajer setuju untuk menerima tanggung jawab untuk mencapai sasaran 
yang telah dianggarkan serta memanfaatkan kesempatan yang ada dan menghindari ancaman yang akan datang baik dari dalam maupun dari luar organisasi. Anggaran akan melaporkan hasil akrual prestasi yang dicapai pada atasan dan dibandingkan kemudian apabila terjadi penyimpangan akan ditelusuri penyebabnya dan dianalisis sehingga dapat secepatnya diambil tindakan koreksi.

f. Fungsi Anggaran Promosi

Fungsi anggaran promosi adalah sebagai pedoman kerja, alat koordinasi kerja dan alat pengawasan kerja yang membantu manajemen dalam memimpin jalannya perusahaan. Sebagai alat perencanaan dan pengendalian biaya yang terpadu penyusunan anggaran promosi yang baik akan menyentuh semua bagian kegiatan dalam perusahaan yang merupakan pencerminan seluruh kegiatan operasional secara terpadu.

Anggaran promosi digunakan untuk tujuan perencanaan dan pengendalian dalam ruang lingkup yang lebih khusus yaitu dalam perencanaan dan pengendalian biaya promosi dan bagaimana cara pengendalian biaya promosi tersebut. Adapun fungsi anggaran promosi dapat diuraikan sebagai berikut :

1) Sebagai Alat Pedoman Kerja Anggaran promosi berfungsi sebagai pedoman kerja dan memberikan arah, memberikan target yang harus dicapai oleh aktivitas perusahaan diwaktu yang akan datang.

2) Sebagai Alat Pengkoordinasian Kerja Sebagai alat pengkoordinasian kerja agar semua begian yang terdapat dalam perusahaan dapat saling menunjang, saling bekerjasama dengan baik untuk mencapai sasaran yang telah ditetapkan sehingga kelancaran jalannya perusahaan akan lebih terjamin.

3) Sebagai Alat Pengawasan Kerja Dapat digunakan sebagai tolok ukur dan alat pembanding dalam menilai (evaluasi) realisasi kegiatan perusahaan dengan membandingkan antara apa yang tertuang di dalam anggaran dengan apa yang dicapai oleh realisasi kerja perusahaan untuk menilai kesuksesan yang dicapai perusahaan.

g. Penjualan

Penjualan dalam arti sederhana adalah proses memindahkan kepemilikan suatu barang dan pemilik pertama mendapatkan uang senilai barang yang berpindah kepemilikan tersebut. Pengertian penjualan semakin berkembang dari waktu ke waktu. Kini penjualan tidak hanya merupakan proses "menukar barang dengan uang" tetapi

didalamnya sudah terdapat unsur membujuk calon pembeli agar membeli barang tersebut. Menurut Kotler (2010 : 150) penjualan adalah :

"A businnes transaction involving the delivery (the giving) of a commodity, an item of merchandise of property, a right, or a service, in exchange for (the receipt of) coach. A promise to pay, or money aquivalent, or for any combination of those item, it is recorded and reported in terms of the ammount of such cash, promise to pay, or money equivalent. " artinya penjualan merupakan suatu transaksi bisnis yang memberikan keuntungan bagi pihak penjual, namun tidak memberi kerugian bagi pihak konsumen, karena konsumen sudah mengetahui harga yang ditetapkan dari kegiatan promosi yang dilakukan perusahaan.

Faktor-faktor yang Mempengaruhi Kegiatan Penjualan Menurut Swastha (2000 ; 406) diantaranya :

1. Kondisi dan Kemampuan Penjual Transaksi jual beli atau pemindahan hak milik secara komersial atas barang dan jasa melibatkan 2 pihak, yaitu pihak penjual sebagai pihak pertama dan pembeli sebagai pihak kedua. Penjual harus dapat meyakinkan kepada pembeli agar dapat mencapai sasaran penjualan yang diharapkan. Untuk maksud tersebut penjual harus memahami beberapa masalah penting yang sangat berkaitan yakni : a) Jenis dan karakteristik barang yang ditawarkan. b) Harga produk. c) Syarat penjualan seperti pembayaran, penghantaran, pelayanan sesudah penjualan, garansi dan lain-lain. 
2. Kondisi Pasar Pasar sebagai kelompok pembeli atau pihak yang menjadi sasaran dalam penjualan dapat pula mempengaruhi kegiatan penjualannya. Faktor-faktor kondisi pasar yang perlu diperhatikan adalah: a) Jenis pasarnya, apakah pasar konsumen, pasar industri, pasar penjual, pasar pemerintah atau pasar internasional.b) Kelompok pembeli atau segmen pasarnya. c) Daya belinya d) Frekuensi pembeliannya e) Keinginan dan kebutuhannya.

Dari upaya-upaya tersebut diatas upaya yang paling berperan dalam meningkatkan penjualan adalah upaya mengenalkan produk perusahaan kepada calon konsumen, yang dilakukan melalui kegiatan promosi. Tentu saja kegiatan promosi ini memerlukan biaya, sehingga perusahaan harus memastikan bahwa biaya yang dikeluarkan benar-benar untuk kegiatan promosi yang dapat menarik perhatian konsumen untuk membeli produk perusahaan.

Dalam manajemen terdapat fungsi penganalisaan, perencanaan, pelaksanaan atau penerapan serta pengawasan. Tahap perencanan merupakan tahap yang menentukan terhadap kelangsungan dan kesuksesan suatu organisasi pemasaran. Proses perencanaan merupakan satu proses yang selalu memandang kedepan atau pada kemungkinan masa akan datang termasuk dalam pengembangan program, kebijakan dan prosedur untuk mencapai tujuan pemasaran.

Perusahaan memiliki konsekuensi seluruh kegiatan perusahaan harus diarahkan untuk mengetahui kebutuhan konsumen dan mampu memberikan kepuasan agar mendapat laba dalam jangka panjang. Organisasi perusahaan yang menerapkan konsep pemasaran ini disebut organisasi pemasaran. Konsep pemasaran juga menyatakan bahwa kunci untuk meraih tujuan organisasi adalah menjadi lebih efektif daripada para pesaing dalam memadukan kegiatan pemasaran guna menetapkan dan memuaskan kebutuhan pasar sasaran. Konsep pemasaran ini bersandar pada empat pilar, yaitu: pasar sasaran, kebutuhan pelanggan, pemasaran terpadu dan profitabilitas.

Dewasa ini konsep pemasaran mengalami perkembangan yang semakin maju sejalan dengan majunya masyarakat dan teknologi. Perusahaan tidak lagi berorientasi hanya pada pembeli saja, akan tetapi berorientasi pada masyarakat atau manusia. Konsep yang demikianlah yang disebut dengan konsep pemasaran masyarakat. Selanjutnya akan dibahas tiga factor penting yang digunakan sebagai dasar dalam konsep pemasaran.

1) Orientasi konsumen Pada intinya, jika suatu perusahaan ingin menerapkan orientasi konsumen ini, maka: a) Menentukan kebutuhan pokok dari pembeli yang akan dilayani dan dipenuhi. b) Memilih kelompok pembeli tertentu sebagai sasaran dalam penjualan. c) Menentukan produk dan program pemasarannya. d) Mengadakan penelitian pada konsumen untuk mengukur, menilai dan menafsirkan keinginan, sikap serta tingkah laku mereka e) Menentukan dan melaksanakan strategi yang paling baik, apakah menitikberatkan pada mutu yang tinggi, harga yang murah atau model yang menarik. 2) Koordinasi dan integrasi dalam perusahaan Untuk memberikan kepuasan secara optimal kepada konsumen, semua elemen pemasaran yang ada harus diintegrasikan. Hindari adanya pertentangan antara perusahaan dengan pasarnya. Salah satu cara penyelesaian untuk mengatasi masalah koordinasi dan integrasi ini dapat menggunakan satu orang yang mempunyai tanggung jawab terhadap seluruh kegiatan pemasaran, yaitu manajer pemasaran. Jadi dapat disimpulkan bahwa setiap orang dan bagian dalam perusahaan turut serta dalam suatu upaya yang terkoordinir untuk memberikan kepuasan konsumen sehingga tujuan perusahaan dapat tercapai. 3) Mendapatkan laba melalui pemuasan konsumen Salah satu tujuan dari perusahaan adalah untuk mendapatkan profit atau laba. Dengan laba tersebut perusahaan bisa tumbuh dan berkembang dengan kemampuan yang lebih besar. Sebenarnya laba merupakan tujuan umum dari sebuah perusahaan. Banyak perusahaan yang mempunyai tujuan lain disamping laba. Dengan menggunakan konsep pemasaran ini, hubungan antara perusahaan dan konsumen akan dapat diperbaiki yang pada akhirnya akan menguntungkan bagi perusahaan. 4) Pengertian Segmentasi Pasar Pasar terdiri atas pembeli dan pembeli berbeda dalam banyak hal. Pasar dapat dibedakan atau disegmentasikan dalam berbagai cara. Pasar bisa diartikan sebagai orang-orang yang mempunyai keinginan untuk puas, uang untuk belanja dan kemauan untuk membelanjakannya. 
Adapun istilah segmentasi pasar dapat didefinisikan sebagai berikut segmentasi pasar adalah kegiatan membagi-bagi pasar yang bersifat heterogen

dari suatu produk ke dalam satuan-satuan pasar (segmen pasar) yang bersifat homogen. Segmentasi pasar ini merupakan suatu falsafah yang berorientasi pada konsumen. Falsafah ini menunjukan usaha untuk meningkatkan ketepatan penetapan sasaran dari suatu perusahaan. Segmen pasar ini dapat dibentuk dengan banyak cara. Dengan mengacu pada demografi atau gaya hidup, segmentasi pasar dapat dilakukan. Ada beberapa pola berbeda yang akan muncul dalam melakukan segmenatasi pasar ini, yaitu: preferesi homogen, preferensi yang tersebar dan preferensi terkelompok. Dengan menyatukan program pemasaran yang ditujukan kepada segmen-segmen pasar yang dituju, manajemen dapat melaksanakan pemasaran dengan lebih baik dan dapat menggunakan sumberdaya pemasaran secara efisien. Segmentasi pasar dapat membantu manajemen dalam hal menyalurkan uang dan usaha ke pasar potensial yang paling menguntungkan, merencanakan produk yang dapat memenuhi permintaan pasar, menentukan cara-cara promosi yang paling efektif, memilih media advertensi, dan mengatur waktu yang sebaik-baiknya. Dalam melakukan segmentasi pasar ini juga perlu suatu alasan yang cukup baik, misalnya, adanya pasar yang bersifat dinamis dan adanya pasar untuk suatu produk tertentu. Akan tetapi tidak semua segmentasi pasar yang dilakukan efektif. Dengan demikian perlu suatu upaya agar segmentasi pasar yang dilakukan itu berjalan sesuai dengan yang diharapkan. Ada beberapa hal yang mungkin perlu untuk diperhatikan dalam melakukan segmentasi, diantaranya : dapat diukur, dalam jumlah besar, dapat diakses dengan mudah, bisa dibedakan serta dapat diambil tindakan. Perusahaan yang mengidentifikasi segmen pasarnya harus bisa mengevaluasi berbagai segmen dan memutuskan berapa banyak segmen yang akan dimasuki. Ada dua faktor penting yang mesti diperhatikan dalam melakukan evaluasi segmen pasar, yaitu daya tarik segmen secara keseluruhan dan sumberdaya perusahaan. Setelah evaluasi dilakukan, perusahaan kemudian mengambil keputusan seberapa banyak segmen yang akan dilayani. Pada tahap evaluasi, ada berapa hal tambahan yang dapat dijadikan pertimbangan untuk memilih segmen yaitu pilihan etika atas pasar sasaran, interelasi dan segmen-super, rencana serangan segmen per segmen dan kerjasama antar segmen.

\section{Biaya Pemasaran}

Menurut Kotler (2000 : 67), biaya pemasaran adalah sejumlah biaya yang dikeluarkan untuk kegiatan pemasaran. Menurut mulyadi (2009 : 487), biaya pemasaran dalam arti sempit dibatasi artinya sebagai biaya penjualan, yaitu biaya-biaya yang dikeluarkan untuk menjual produk ke pasar. Sedangkan biaya pemasaran dalam arti luas meliputi semua biaya yang terjadi sejak saat produk selesai diproduksi dan disimpan dalam gudang sampai dengan produk tersebut diubah kembali dalam bentuk uamg tunai. Menurut women (2007 : 47),biaya pemasaran adalah biaya-biaya yang diperlukan untuk memasarkan produk atau jasa, meliputi biaya gaji dan komisi tenaga jual, biaya iklan, biaya transportasi, biaya pergudangan dan biaya pelanggan. Menurut Faizal (2007 : 37), biaya pemasaran atau penjualan (marketing cost) meliputi semua biaya yang dikeluarkan untuk mendapatkan pesanan pelanggan dan menyerahkan produk atau jasa ketangan pelanggan. Menurut Bustami (2009 : 14), biaya pemasaran adalah biaya yang dikeluarkan ketika produk selesai dan siap dipasarkan kepada konsumen. Menurut swastha (2007 : 34), biaya pemasaran biaya yang dikeluarkan untuk memuaskan keinginan dan kebutuhan konsumen melalui proses pertukaran. Menurut alma (2007 : 2), biaya pemasaran adalah biaya yang dikeluarkan untuk memasarkan atau mendistribusikan produk dari proses produksi hingga ke konsumen akhir, memoti penjualan, dengan keuntungan sebagai imbalannya.

Dari pengertian di atas dapat di simpulkan bahwa biaya pemasaran merupakan biaya yang digunakan untuk memasarkan produk kepada publik atau masyarakat seperti biaya promosi, distribusi dan lain-lain yang berkaitan dengan pemasaran produk itu sendiri. Secara garis besar biaya pemasaran dapat digolongkan ke dalam 2 bagian yaitu :

a. Biaya untuk mendapatkan pesanan (order-getting cost), yaitu biaya yang dikeluarkan dalam usaha untuk memperoleh pesanan. Contohnya biaya gaji wiraniaga (sales person), 
komisi penjualan, advertensi dan promosi.

b. Biaya untuk memenuhi pesanan (order-filling cost), yaitu semua biaya yang dikeluarkan untuk mengusahakan supaya produk sampai ke tangan pembeli dan biaya-biaya untuk mengumpulkan piutang dari pembeli. Contohnya biaya pergudangan, biaya pembungkusan dan pengiriman, biaya angkutan dan biaya penagihan.

\section{Kinerja}

Pengertian kinerja menurut Sulistiyani (2003: 223), kinerja seseorang merupakan kombinasi dari kemampuan, usaha, dan kesempatan yang dapat dinilai dari hasil kerjanya. Kinerja keuangan adalah gambaran setiap hasil ekonomi yang mampu di raih oleh perusahaan pada periode tertentu melalui aktivitasaktivitas perusahaan untuk menghasilkan keuntungan secara efisien dan efektif, yang dapat diukur perkembangannya dengan mengadakan analisis terhadap data-data keuangan yang tercermin dalam laporan keuangan.

Kinerja (performance) dalam kamus istilah akuntansi adalah kuantifikasi dari keefektifan dalam pengoperasian bisnis selama periode tertentu. Kinerja secara umum merupakan gambaran prestasi yang dicapai oleh perusahaan dalam operasionalnya. Kinerja keuangan merupakan gambaran kondisi keuangan perusahaan pada suatu periode tertentu baik mencakup aspek penghimpunan dana maupun penyaluran dananya. Kinerja menunjukkan sesuatu yang berhubungan dengan kekuatan serta kelemahan suatu perusahaan.

Kinerja perusahaan dapat di ukur dengan menganalisa dan mengevaluasi laporan keuangan. Informasi posisi keuangan dan kinerja keuangan di masa lalu seringkali di gunakan sebagai dasar untuk memprediksi posisi keuangan dan kinerja di masa depan dan hal lain yang langsung menarik perhatian pemakai seperti pembayaran dividen, upah, pergerakan harga sekuritas dan kemampuan perusahaan untuk memenuhi komitmennya ketika jatuh tempo.

Informasi kinerja perusahaan terutama profitabilitas diperlukan untuk menilai perubahan potensi sumber daya ekonomi yang mungkin di kendalikan di masa depan. Informasi fluktuasi kinerja bermanfaat untuk memprediksi kapasitas perusahaan dalam menghasilkan arus kas dari sumber daya yang ada, disamping itu informasi tersebut juga dapat berguna dalam perumusan pertimbangan tentang efektifitas perusahaan dalam memanfaatkan tambahan sumber daya. Rasio merupakan alat ukur yang digunakan dalam perusahaan untuk menganalisis laporan keuangan. Rasio menggambarkan suatu hubungan atau pertimbangan antara suatu jumlah tertentu dengan jumlah yang lain. Dengan menggunakan alat analisa yang berupa rasio keuangan dapat menjelaskan dan memberikan gambaran kepada penganalisa tentang baik dan buruknya keadaan atau posisi keuangan dari suatu periode ke periode berikutnya.

\section{Standar Penentuan Kinerja Perusahaan}

Berdasarkan kebijakan perusahaan menetapkan pedoman anggaran biaya pemasaran yang mana penyimpangan yang tidak menguntungkan jika pendapatan di bawah Rp 2.000.000.000, maka dilakukan tindakan korektif. Dillihat dari metode times series terhadap anggara biaya pemasaran dapat dikatakan bahwa PT. Penerbit Erlangga Cabang Bengkulu mengalami penyimpangan yang menguntungkan (favorable) sehingga perusahaan tidak melakukan

tindakan korektif karena anggaran biaya pemasaran sudah cukup efesien berdasarkan pedoman yang telah ditetapkan oleh perusahaan.

\section{Kerangka Analisis}

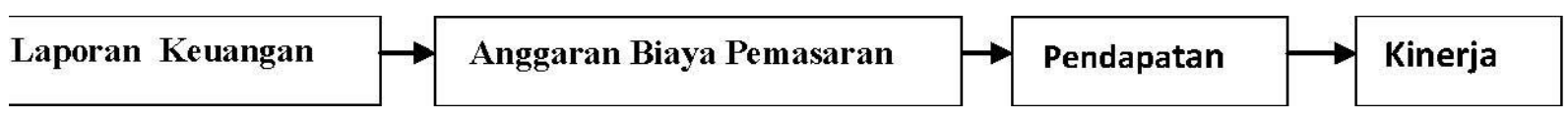

Gambar 1. Kerangka Analisis 


\section{HASIL DAN PEMBAHASAN}

\section{Analisis Biaya Pemasaran}

Berdasarkan hasil analisis deskriptif komparatif yang telah dilakukan untuk mendapatkan analisis anggaran biaya pemasaran sebagai alat penilaian kinerja pada PT. Penerbit Erlangga Cabang Bengkulu, dapat dilihat pada tabel di bawah.

Tabel 1. Anggaran Biaya dan Pendapat PT. Penerbit Erlangga Cabang Bengkulu Tahun 2007 2012 ( Dalam Rupiah)

\begin{tabular}{||l||l||l||l||l||}
\hline \hline TAHUN & ANGGARAN & PENDAPATAN & VARIANS & KINERJA \\
\hline \hline 2007 & Rp 1.034.506.200 & Rp 3.371.009.000 & Rp 2.336.502.800 & BAIK \\
\hline \hline 2008 & Rp 1.046.334.000 & Rp 3.570.227.000 & Rp 2.523.893.000 & BAIK \\
\hline \hline 2009 & Rp 975.396.000 & Rp 2.150.052.000 & Rp 1.174.656.000 & KURANG \\
\hline \hline 2010 & Rp 995.146.200 & Rp 3.081.509.000 & Rp 2.126.362.800 & BAIK \\
\hline \hline 2011 & Rp 1.178.225.000 & Rp 3.983.909.000 & Rp 2.805.684.000 & BAIK \\
\hline \hline 2012 & Rp 1.587.408.000 & Rp 5.412.809.000 & Rp 3.825.401.000 & BAIK \\
\hline
\end{tabular}

Sumber : Lapaorang Keuangan PT. Penerbit Erlangga Cabang Bengkulu Tahun 2007-20012 (Data diolah) Berdasarkan hasil analisis deskriptif komparatif di atas, dapat dibandingkan antara anggaran biaya pemasaran dengan pendapatan yang terjadi pada tahun 2007 dengan tahun 2008. Pada tahun 2007 anggaran biaya pemasaran sebesar $\mathrm{Rp}$ 1.034.506.200, dari anggaran tersebut di peroleh pendapatan sebesar $\mathrm{Rp}$ 3.370.009.000. Sedangkan pada tahun 2008, besarnya anggaran biaya pemasaran Rp 1.046.334.000 dengan pendapatan $\mathrm{Rp}$

3.570.227.000. dari perbandingan tersebut dapat dikatakan bahwa semakin besarnya anggaran biaya pemasaran, semakin besar pula pendapatan yang akan di terima.

Dari hasil analisis data di atas, jika dilihat dari sisi perbandingan dari tahun 2007 sampai dengan tahun 2012, anggaran biaya pemasaran yang paling rendah adalah terjadi pada tahun 2009 besarnya anggaran biaya pemasaran $\mathrm{Rp}$

975.396.000. dari anggaran biaya pemasaran tersebut perusahaan memperoleh pendapatan Rp 2.150.052.000. ini terjadi karena perusahaan mencoba untuk meminimalisir anggaran biaya pemasaran. Sedangkan anggaran biaya pemasaran yang paling tinggi terjadi pada tahun 2012, dimana besarnya anggaran biaya pemasaran Rp1.587.408.000, dari anggaran biaya pemasaran tersebut perusahan memperoleh pendapatan sebesar Rp 5.412.809.000. Dari perbandingan tersebut diatas berdasarkan teori Nafarin (2000:9) "besarnya anggaran biaya pemasaran sangat berpengaruhi positif terhadap besarnya pendapatan yang akan diterima oleh perusahaan.

Jika dilihat secara keseluruhan anggaran biaya pemasaran dalam periode pertahun bahwa kinerja perusahaan mengalami perbaikan, karena penyimpangan selain mengalami penurunan juga penyimpangan itu masih dalam batas toleransi yang telah ditetapkan oleh perusahaan. Jadi penyimpangan tersebut dapat dikatakan masih dalam kewajaran.

Dengan demikian dapat dikatakan bahwa anggaran biaya pemasaran telah digunakan sebagai alat penilaian untuk mengukur kinerja perusahaan, karena berdasarkan hasil laporan evaluasi kinerja keuangan yang disampaikan oleh BPKP menunjukkan anggaran perusahaan yang disebut sebagai Rencana Kerja dan Anggaran Perusahaan (RKAP) telah digunakan sebagaia salah satu indikator pengukuran selain rasio-rasio keuangan.

Perencanaan merupakan usaha sistematis untuk mencapai tujuan dengan cara membandingkan pendapatan dengan anggaran biaya itu sendiri. Kegiatan harus terus menerus diawasi jika manajemennya ingin tetap berasa pada batasbatas ketentuan yang digariskan. Hasil nyata yang telah direalisasikan dari tiap kegiatan harus diperbandingkan dengan rencana dan bila terdapat perbedaan yang besar, maka dievaluasi dan dianalisis apa yang menyebabkan perbedaan serta diambil tindakan perbaikan.

Analisis anggaran biaya pemasaran sebagai alat penilaian kinerja yang peneliti lakukan 
bertujuan untuk membandingkan antara anggaran biaya pemasaran dengan pendapatan. Tipe pengukuran kinerja yang oleh PT.Penerbit Erlangga Cabang Bengkulu digolongkan pada tipe feedback Control, tipe ini merupakan hasil dari pengukuran kinerja keuangan dari suatu kegiatan yang telah dilaksanakan, hal ini dapat dilihat dari cara yang diterapkan perusahaan dmana perusahaan membandingkan pendapatan yang telah dicapai dengan anggaran biaya yang telah ditetapkan. Setelah perbandingan tersebut maka perusahaan dapat diketahui apabila ditemukan penyimpangan-penyimpangan, maka perusahaan akan mengambil tindakan korektif (corretive Action).

Berdasarkan kebijakan perusahaan, perusahaan menetapkan pedoman anggaran biaya pemasaran yang mana penyimpangan yang tidak menguntungkan jika pendapatan dibawah Rp 2.000.000.000, maka dilakukan tindakan korektif. Dilihat dari metode time series terhadap anggaran biaya pemasaran dapat dikatan bahawa PT. Penerbit Erlangga Cabang Bengkulu mengalami penyimpangan yang menguntungkan (favorable) sehingga perusahaan tidak melakukan tindakan korektif karena angaran biaya pemasaran sudah cukup efesien berdasarkan pedoman yang telah ditetapkan oleh perusahaan.

\section{Kesimpulan}

Berdasarkan rumusan masalah yang kemudian dilakukan analisis deskriptif komparatif terhadap data-data maka dapat diambil beberapa kesimpulan, yaitu :

a. Jika dilihat secara keseluruhan (dari tahun 2007 sampai dengan tahun 2012), selisih yang menguntungkan antara anggaran biaya pemasaran dengan pendapatan terjadi pada tahun $2007,2008,2010,2011,2012$. Sedangkan yang kurang menguntungkan hanya terjadi pada tahun 2009, berarti anggaran biaya pemasaran dapat dijadikan sebagai alat penilaian kinerja pada PT. Penerbit Erlangga Cabang Bengkulu.

b. Dari data yang ada, menunjukkan bahwa anggaran biaya sudah berfungsi sebagai alat penilaian kinerja, karena dalam menilai kinerja pada tiap cabang perusahaan membandingkan antara anggaran dan pendapatan yang kemudian ditelusuri penyebab terjadinya penyimpangan itu sendiri.

c. Standar pedoman pendapatan yang tetapkan oleh perusahaan Rp 2.000.000.000, jika kurang maka dilakukan tindakan korektif. Dilihat dari metode time series terhadap anggaran biaya pemasaran dapat dikatan bahawa PT. Penerbit Erlangga Cabang Bengkulu mengalami penyimpangan yang menguntungkan (favorable)

\section{Saran}

Dari kesimpulan di atas maka penulis menyarankan kepada perusahaan antara lain :

a. Sebaiknya biaya-biaya yang pasti terealisasi setiap tahunnya dibuat dalam anggaran perusahaan, hal ini untuk menghindari penyimpangan yang tidak menguntungkan dalam jumlah dan persen yang cukup besar.

b. Selain untuk meningkatkan kinerja perusahaan atas penggunaan biaya, sebaiknya menetapkan hukuman atau sanksi apabila tidak tercapai kinerja yang diharapkan oleh manajemen. Hal ini dilakukan untuk memotivasi para manajer maupun bawahan untuk bekerja lebih baik yang dapat meningkatkan kinerja.

c. Perlu adanya komitmen bersama pada seluruh variabel level manajemen perusahaan terhadap anggaran biaya yang telah ditetapkan, sehingga dapat dicapai tujuan perusahaan dari penetapan anggaran biaya tersebut.

\section{DAFTAR PUSTAKA}

Mulyadi, 2001. Akuntansi Biaya. Yogyakarta : STIE YKPN

2001. Manajemen Pemasaran. Yogyakarta : STIE YKPN 
2005. Akuntansi Biaya,edisi ke-6. Yogyakarta: STIE YKPN

Supriyono, 2000. Akuntansi Biaya, Buku 1, edisi dua. Yogyakarta: BPFE

Hansen \& Mowen, 2000. Manajemen Biaya. Edisi bahasa Indonesia, Buku Dua, Edisi Pertama. Jakarta: Salemba Empat

Kotler, Philip, 2010, Marketing 3.0, Jakarta: Erlangga.

2010, Mananajem Pemasaran, Jakarta : LPFE -UI

2010, Manajemen Pemasaran analisis, biaya Pemasaran, Jakarta : LPFE -UI

Swasta, Basu, 2000, Manajemen Pemasaran, Jakarta : LPFE -UI

2009, Manajemen Pemasaran, Jakarta : LPFE -UI

Adisaputra, Gunawan dan Asri Marwan, 2003. Penganggaran, PT. Gramedia Jakarta

Munandar.M. 2002, Penganggaran.. Yogyakarta : Liberty

Nafarin.M. 2000, Konsep Pemasaran, Jakarta : LPFE -UI

Rudianto, 2009. Penganggaran, Jakarta : PT. Penerbit Erlangga

2009. Konsep Penyusunan Anggaran. Jakarta : PT. Penerbit Erlangga

Sulistiyani, Ambar T. dan Rosidah.2003. Manajemen Sumber Daya Manusia, Yogyakarta : Graha Ilmu

http//:www.erlangga.co.id Sejarah Singkat PT. Penerbit Erlangga. 